\title{
Desorption of phosphate from three Finnish mineral soil samples during adsorption of vanadate, molybdate and tungstate
}

\author{
ANNeli MikKonen and Jouni TUMmaVuori
}

\begin{abstract}
Miknonen, A. \& Tummavuori, J. 1994. Desorption of phosphate from three Finnish mineral soil samples during adsorption of vanadate, molybdate, and tungstate. Agricultural Science in Finland 3: 481-486. (Department of Chemistry, University of Jyväskylä, P.O.Box 35, FIN-40351 Jyväskylä.)
\end{abstract}

Adsorption of $\mathrm{V}(\mathrm{V})$ and $\mathrm{Mo}(\mathrm{VI})$ from $10^{-4} \mathrm{M}$ and $10^{-5} \mathrm{M}$ solutions and $\mathrm{W}(\mathrm{VI})$ from a $10^{-4} \mathrm{M}$ solution (in $0.02 \mathrm{M} \mathrm{KCl}$ ) by three Finnish mineral soils was studied in two series of experiments.

In the first experiment, the adsorption of $\mathrm{V}$, Mo and $\mathrm{W}$ by soil and the desorption of $\mathrm{P}$ were measured at the soils' natural $\mathrm{pH}$ after an equilibration time of $3,5,22$, 29,46 and $70 \mathrm{~h}$. Adsorption of molybdate occurred mainly within the three first hours, whereas adsorption of vanadate and tungstate were slower processes. During the first few hours, the presence of molybdate seemed to increase the desorption of phosphate most effectively, but after a longer equilibration period, the differences between additions of $\mathrm{V}, \mathrm{Mo}$, and $\mathrm{W}$ became smaller.

In the second experiment, the adsorption process was followed as a function of the acidity of the suspension ( $\mathrm{pH} 2.3-7.5$; for $\mathrm{W}$ pH 2.8-7.5). Adsorption of $\mathrm{V}(\mathrm{V})$, $\mathrm{Mo}$ (VI) or W(VI) resulted in a statistically significant increase in the amounts of $\mathrm{P}$ desorbed from all three soils over the $\mathrm{pH}$ range studied.

The aqueous chemistry of $\mathrm{V}(\mathrm{V}), \mathrm{Mo}(\mathrm{VI})$ and $\mathrm{W}(\mathrm{VI})$ is briefly discussed.

Key words: clay, finesand, anions, polyanions, specific adsorption

\section{Introduction}

In studying adsorption of anions by different materials, soils, without doubt, are the most complicated adsorbents. Even in simplified adsorption and desorption experiments carried out in laboratory conditions, processes such as cation and anion exchange, dissolution of fertilizer particles or soil constituents, and precipitation can be expected (LINDSAY 1979, BARBER 1984). When different anions are present in soil solution or in the solution in contact with adsorbent, competitive adsorption may occur (MURALI and AYLMORE 1983, Roy et al. 1986a,b, GoldberG and TrainA
1987, Roy et al. 1989, BARRow 1989, MiKKONEN and Tummavuori 1993a). Addition of a specifically adsorbed ion may affect desorption of other ions already adsorbed (GoRLACH et al. 1969, BARRow 1974).

When studying retention of $\mathrm{V}(\mathrm{V}), \mathrm{Mo}(\mathrm{VI})$ and W(VI) by three Finnish soils from sodium oxysalt solutions (MIKKONEN and TUMMAVUORI 1993 b,c,d), we followed how quickly adsorption of $\mathrm{V}$, Mo and $\mathrm{W}$ occurs at the natural soil $\mathrm{pH}$ and how much $\mathrm{P}$ is released to the aqueous phase. In addition, we measured the amounts of $\mathrm{P}$ present in the aqueous phase at the end of the 72-hour equilibration period to see if the desorption of phos- 
phate is affected by the addition of rather high amounts of these anions.

The reasons for using $10^{-4} \mathrm{M}$ and $10^{-5} \mathrm{M}$ solutions of added anions was that batch analyses were comfortable to perform at these concentrations and there were no polyanionic species present in molybdate solutions. Molybdate is the most important of these three analytes.

At $\mathrm{pH} 2-8$, in dilute $\left(\leq 10^{-4} \mathrm{~mol} / \mathrm{l}\right)$ solutions, $\mathrm{Mo}(\mathrm{VI})$ is present as monomeric species $\mathrm{Mo}(\mathrm{OH})_{6}$, $\mathrm{HMoO}_{4}^{-}$, and $\mathrm{MoO}_{4}{ }^{2-}$, the last one being predominant at $\mathrm{pH}>4.5$. At concentrations $>10^{-4} \mathrm{~mol} / \mathrm{l}$, polyanions, such as $\mathrm{Mo}_{7} \mathrm{O}_{24}{ }^{6-}$ and its protonated forms, may be present at $\mathrm{pH} \leq 5$. In $\mathrm{V}(\mathrm{V})$ solutions, at $\mathrm{pH} \leq 5$, polyionic decavanadate species $\mathrm{HV}_{10} \mathrm{O}_{28}{ }^{5-}$ and $\mathrm{H}_{2} \mathrm{~V}_{10} \mathrm{O}_{28}{ }^{4-}$ exist even in a low concentration such as $10^{-4} \mathrm{~mol} / \mathrm{l}$. In $10^{-5} \mathrm{M}$ solutions, only $\mathrm{H}_{3} \mathrm{VO}_{4}, \mathrm{H}_{2} \mathrm{VO}_{4}^{-}$and small amounts of $\mathrm{HVO}_{4}{ }^{2-}$ are present at $\mathrm{pH} 2-8$. The solution chemistry of tungsten is even more unknown. As yet, the equilibria and ionic forms in $\leq 10^{-3} \mathrm{M} \mathrm{W}$ (VI) solutions are not precisely known (POPE 1983, MAKSIMOVSKAYA and BURTSEVA 1985, CRUYWAGEN and VAN DER MERWE 1987).

In addition to the isopolyanions mentioned above, it is possible that $\mathrm{V}(\mathrm{V}), \mathrm{Mo}(\mathrm{VI})$, and $\mathrm{W}(\mathrm{VI})$ form heteropolyanions with each other or with many other elements present in aqueous solutions. Examples of such heteropolyanions that might also occur in soil suspensions are molybdophosphates $\left(\mathrm{H}^{+}\right)_{\mathrm{p}}\left(\mathrm{MoO}_{4}{ }^{2-}\right)_{5}\left(\mathrm{HPO}_{4}{ }^{2-}\right)_{2}, \mathrm{p}=8,9,10$ (PETTERSSON et al. 1985) and tetra-decavanadophosphate $\mathrm{HPV}_{14} \mathrm{O}_{42}{ }^{8-}$ (HARRISON and HowARTH 1985). Both of these have been shown to exist in laboratory conditions, using high ionic strength and $10^{-3}-10^{-2} \mathrm{M}$ solutions. At present, it is still uncertain if these kinds of species exist in very dilute solutions.

\section{Material and methods}

Test soils were a clay (soil 1) and two finesand samples (soils 2 and 3). Soil 2 had the coarsest texture. Selected characteristics of the soils are given in Table 1. The ammonium oxalate-oxalic acid ( $\mathrm{pH}$ 3.3) extractable amounts of Mo and W, and $\mathrm{HClO}_{4}+\mathrm{HNO}_{3}$-extractable amounts of $\mathrm{V}$ are given in our previous papers (MIKKONEN and TUMMAVUORI 1993b,c,d).

The soils were air-dried and hand-crushed to pass through a 2-mm sieve. When measuring adsorption of $\mathrm{V}, \mathrm{Mo}$ and $\mathrm{W}$ as a function of time, aliquots of $100.0 \mathrm{ml}$ of $10^{-4} \mathrm{M} \mathrm{NaVO}_{3}$, $\mathrm{Na}_{2} \mathrm{MoO}_{4}$, or $\mathrm{Na}_{2} \mathrm{WO}_{4}$, all in $0.02 \mathrm{M} \mathrm{KCl}$, were mixed to the 1.00-g samples of soils (two replicates) in 250-ml beakers, covered with Parafilm and allowed to equilibrate for $3,5,22,29,46$, and $70 \mathrm{~h}$ at room temperature. Before filtration, the $\mathrm{pH}$ values of the suspensions were measured. From these filtrates, V, Mo or $\mathrm{W}$ as well as $\mathrm{P}$ concentrations were measured by Perkin-Elmer ICP 2000.

For experiments, where adsorption was studied as a function of $\mathrm{pH}$, subsamples of $1.00 \mathrm{~g}$ were placed into 250-beakers and aliquots of $100.0 \mathrm{ml}$ of $0.02 \mathrm{M} \mathrm{KCl}, 10^{-4}$ or $10^{-5} \mathrm{M} \mathrm{Na}_{2} \mathrm{MoO}_{4}$, $10^{-4} \mathrm{M} \mathrm{Na}_{2} \mathrm{WO}_{4}$, or $10^{-4}$ or $10^{-5} \mathrm{M} \mathrm{NaVO}_{3}$, all in $0.02 \mathrm{M} \mathrm{KCl}$ were added. $\mathrm{KCl}$ was used to keep the ionic strength constant. $\mathrm{pH}$ adjustments to obtain final $\mathrm{pH} 2.3-7.5$ were made by adding dilute $\mathrm{HCl}$ or $\mathrm{NaOH}$. The beakers were covered with Parafilm, shaken manually for 2$3 \mathrm{~min}$, and left to equilibrate at room temperature for $72 \mathrm{~h}$. The final $\mathrm{pH}$ values of the suspensions were recorded prior to the filtration using a standard combination electrode. During the $\mathrm{pH}$ measurements, the samples were stirred using a magnetic rod. The samples were then filtered through Whatman 40 filter paper, and the concentrations of the analytes in the filtrates were measured by a Perkin-Elmer ICP 5000 spectrophotometer. The concentrations were volume-corrected because of the $\mathrm{H}^{+} / \mathrm{OH}^{-}$addition. From each soil, arbitrarily-selected filtrates were also analysed using the standard addition method, so that the accuracy of the ICP measurements was checked both for the blank samples and for the samples into which $\mathrm{V}$, Mo or $\mathrm{W}$ was added. The added 100.0-ml aliquots of $10^{-4}$ M V, Mo or W solution contained $509.4 \mu \mathrm{g}$ of $\mathrm{V}$, $959.4 \mu \mathrm{g}$ of $\mathrm{Mo}$ and $1838.5 \mu \mathrm{g}$ of $\mathrm{W}$, respectively. 
Table 1. Selected characteristics of the soil samples.

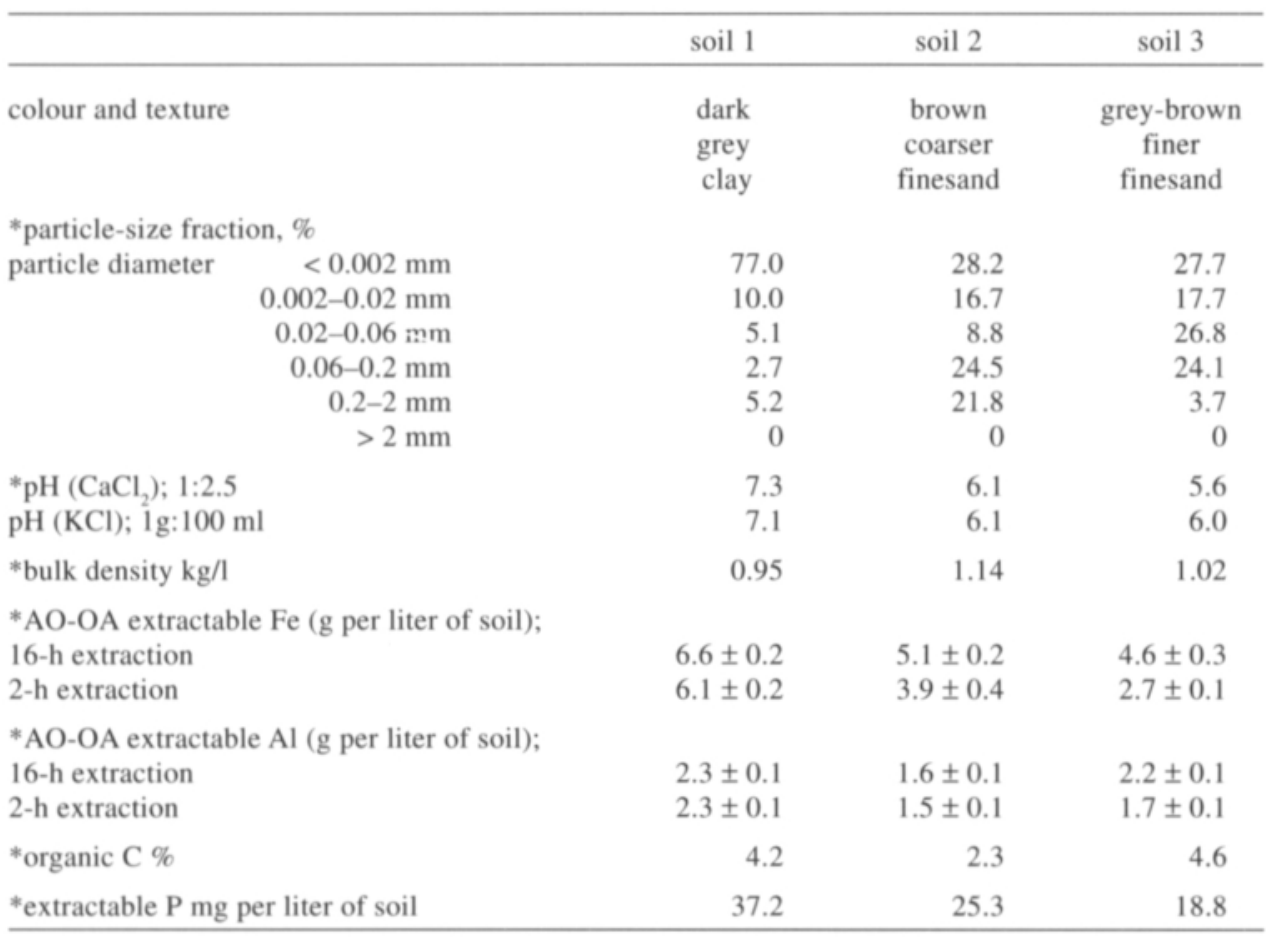

* = A determination made at the Agricultural Research Centre of Finland, Jokioinen.

$\mathrm{AO}-\mathrm{OA}=$ ammonium oxalate-oxalic acid extraction solution, $\mathrm{pH} 3.3$

\section{Results and discussion}

Adsorption of $\mathrm{V}$, Mo and $\mathrm{W}$ begins within the first three hours, but adsorption of vanadate occurs more slowly than adsorption of molybdate or tungstate (Fig. 1a-c). The $\mathrm{pH}$ remained rather constant in all samples.

Figures 1a-1c show that during the 70-h equilibration period, 33-55\% (170-280 $\mathrm{gg} / \mathrm{g})$ of added V, 3-10\% (30-100 $\mu \mathrm{g} / \mathrm{g})$ of added Mo and $21-33 \%(400-600 \mu \mathrm{g} / \mathrm{g})$ of added W (Fig. 1c) were retained. Vanadate is retained most strongly in neutral conditions, but the order becomes different when the suspensions are acidic (МıккоNEN and TUMMAVUORI 1993b,c,d).

If we take a $30-\mathrm{cm}$ layer of soil and use a bulk density of $1.00 \mathrm{~kg} / \mathrm{l}$, the soils could retain at least $510-840 \mathrm{~kg} / \mathrm{ha}$ of $\mathrm{V}, 90-300 \mathrm{~kg} / \mathrm{ha}$ of $\mathrm{Mo}$, and
$1200-1800 \mathrm{~kg} / \mathrm{ha}$ of $\mathrm{W}$, respectively. These are, of course, only estimates, because the adsorption capacity was not determined using a series of more concentrated solutions.

In addition that phosphate can displace e.g. adsorbed molybdate, phosphate can be displaced by high amounts of other specifically adsorbed anions. Within the first few hours, the presence of molybdate seems to increase the desorption of phosphate most, but after a longer equilibration period, the differences in displacing ability of $\mathrm{V}$, Mo, and $\mathrm{W}$ become smaller (Fig. 2a-c).

The desorption of $\mathrm{P}$ from the blank samples in $72 \mathrm{~h}$ and the changes in the desorption because of the addition of Mo (at the $10^{-4} \mathrm{~mol} / \mathrm{l}$ level) as a function of $\mathrm{pH}$ are presented in Fig. 3. The differences in the shape of the curves of soils 2 and 3 at $\mathrm{pH}>6$ compared with that of soil 1 are 
a) $\mathrm{v}(\mathrm{ads}) \mu \mathrm{g} / \mathrm{g}$

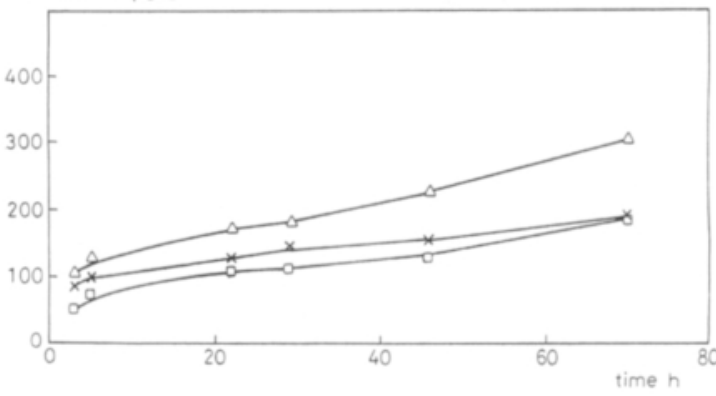

$\rightarrow$ soil $1 \quad \longrightarrow$ soil $2 \quad x$ soil 3

C) $W($ ads $) \mu g / g$

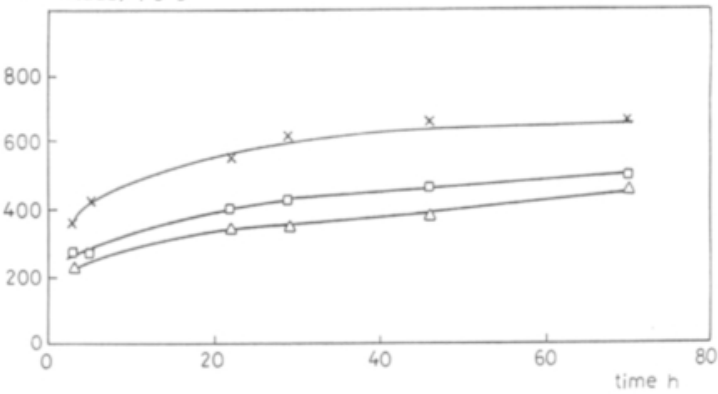

$\leadsto$ soil $1 \quad \multimap$ soil $2 \quad *$ soil 3

a)

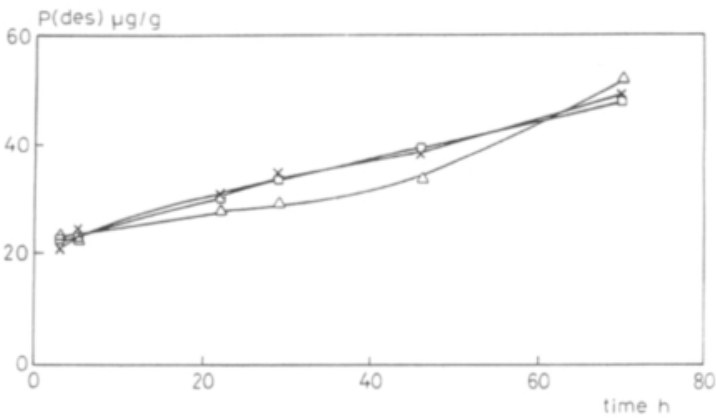

c)

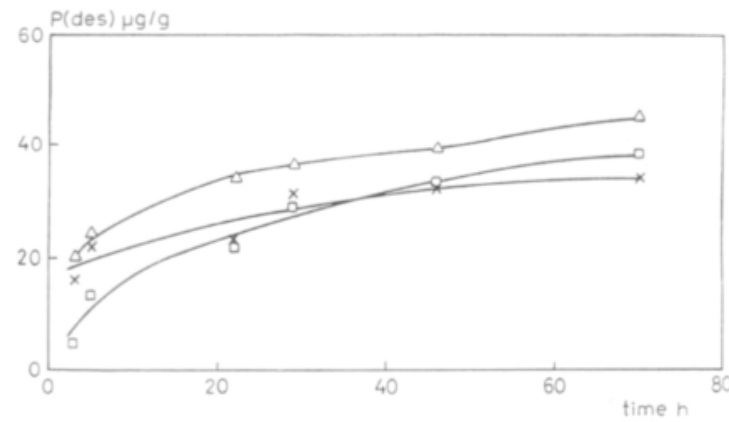

$\rightarrow$ soil $1 \quad \rightarrow$ soil $2 \quad *$ soil 3 b) $M o(a d s) \mu q / q$

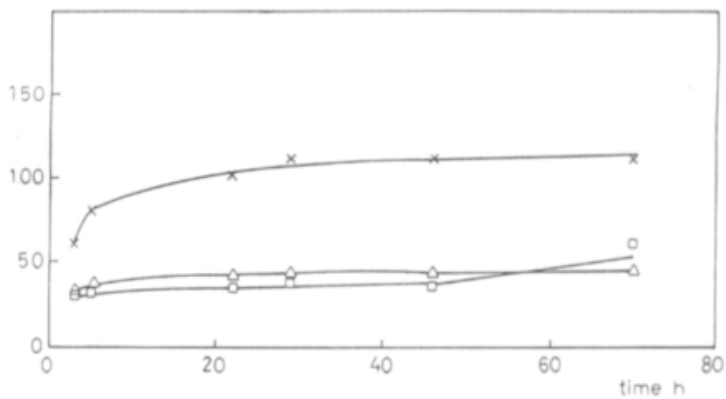

$\multimap$ soil $1 \quad \longrightarrow$ soil $2 \quad \nVdash$ soil 3

Fig. 1. Time-dependence of adsorption from a $10^{-4} \mathrm{M}$ solution. a) V, b) Mo, c) W. Error limits $\leq 5 \%$.

b)

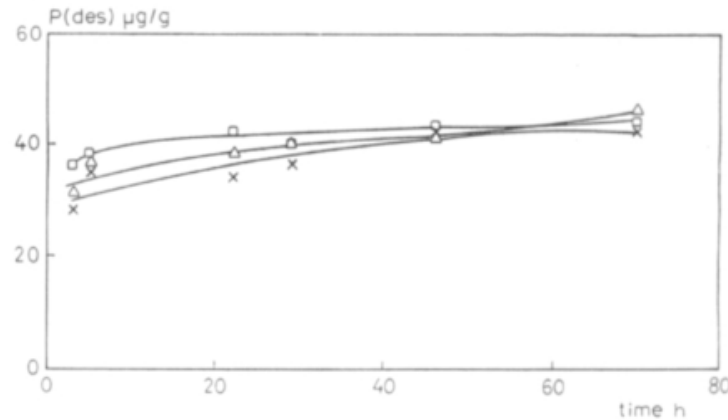

$\rightarrow$ soil $1 \quad \rightarrow$ soil $2 \quad *$ soil 3

Fig. 2. Time-dependence of desorption of $\mathrm{P}$ during adsorption of a) V, b) Mo, c) W. Error limits $\leq 8 \%$. 


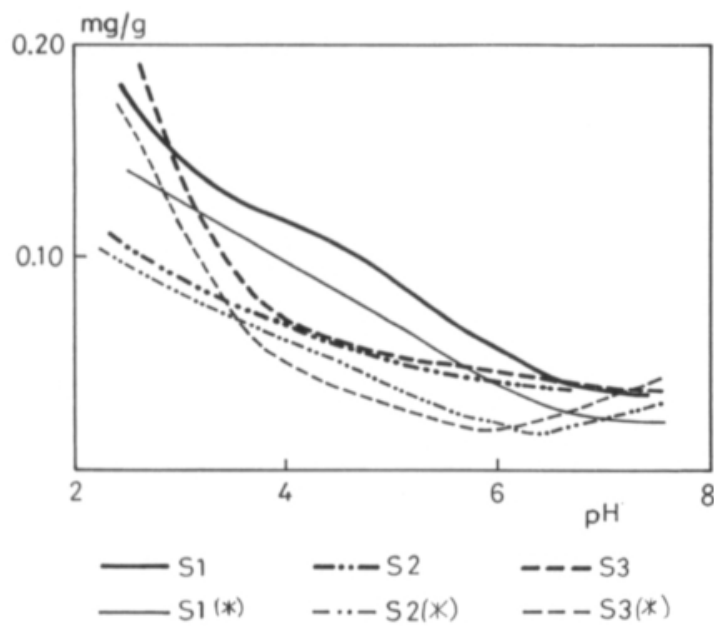

Fig. 3. Mobility of $P$ from the blank samples and changes caused by the addition of $10^{-4} \mathrm{M}$ molybdate. $\mathrm{S} 1=$ soil 1 , $\mathrm{S} 2$ = soil $2, \mathrm{~S} 3=$ soil $3 ;\left({ }^{*}\right)$ denotes blank samples.

attributable to the addition of $\mathrm{OH}^{-}$ions that displaced some of the adsorbed phosphate ions. Because the natural $\mathrm{pH}$ of soil 1 was 7.3 , no addition of $\mathrm{OH}^{-}$ions was necessary for obtaining final high $\mathrm{pH}$ values of 6-7. In the most acidic suspensions, phosphorus bound to oxide surfaces or present in apatitic form or in the organic matter may also begin to dissolve, in addition to the other forms of $\mathrm{P}$ in soil.

In statistical analyses, the results at $\mathrm{pH} 2.3-$ $7.5(\mathrm{pH} 2.8-7.5$ for $\mathrm{W})$ after every $\mathrm{V} / \mathrm{Mo} / \mathrm{W}$ treatment were used as one group of test points. A paired t-test confirmed that the sieved soils were homogenous enough for accurate analytical work. When pairs of test points after each $\mathrm{V} / \mathrm{Mo} / \mathrm{W}$ application were divided into two subgroups and the means of the latter compared, the means were identical only when the $\mathrm{pH}$ of the test pairs was within $0.05 \mathrm{pH}$ units.

ANOVA was used for statistically testing the effect of adding competing anions on the desorption of P (Table 2). The statistical tests showed that addition of a foreign heavy metal $(\mathrm{V}, \mathrm{Mo}$, W) as sodium oxosalt increased the release of $\mathrm{P}$ from all soils. A correlation between adsorbed Mo, V, or W, and desorbed P, however, existed only in the case of W (Table 3 ). This correlation
Table 2. P-release from untreated soils and differences in means of desorbed $\mathrm{P}$ from soil samples with a Mo, V, or $\mathrm{W}$ application compared to means of amounts desorbed from blank samples.

\begin{tabular}{|c|c|c|c|}
\hline \multirow[t]{2}{*}{ Set of samples } & \multicolumn{3}{|c|}{$\begin{array}{l}\text { the statistical significance of the } \\
\text { differences }\end{array}$} \\
\hline & soil 1 & soil 2 & soil 3 \\
\hline blank mean $\mu \mathrm{g} / \mathrm{g}$ & 47.5 & 47.3 & 62.3 \\
\hline $10^{-4} \mathrm{M} \mathrm{Mo}$ & $* * *$ & $* * *$ & $* * *$ \\
\hline $10^{-5}$ M Mo & NS & $*$ & $*$ \\
\hline $10^{-4} \mathrm{M} \mathrm{W}$ & $* * *$ & $* * *$ & $* *$ \\
\hline $10^{-4} \mathrm{M} \mathrm{V}$ & $* * *$ & $* * *$ & $*$ \\
\hline $10^{-5} \mathrm{M} \mathrm{V}$ & $* * *$ & $* * *$ & $*$ \\
\hline \multicolumn{4}{|l|}{$* \quad=\mathrm{P}(>0.05)$} \\
\hline \multicolumn{4}{|l|}{$* *=\mathrm{P}(>0.01)$} \\
\hline \multicolumn{4}{|l|}{$* * *=\mathrm{P}(>0.001)$} \\
\hline NS $=$ not signific & & & \\
\hline
\end{tabular}

is linear at $\mathrm{pH} 3-6$. Both at low solubility of $\mathrm{P}$ at $\mathrm{pH} \mathrm{6-7} \mathrm{and} \mathrm{at} \mathrm{high} \mathrm{solubility} \mathrm{of} \mathrm{P} \mathrm{from} \mathrm{soil} 3$ at $\mathrm{pH}<3$, the W-P correlation deviates from a straight line.

In creating adsorption isotherms and adsorption envelopes, solution chemistry, properties of the adsorbent, and the analytical conditions should all be taken into account. Today, scientists should carefully investigate especially the possibility of vanadium's forming heteropolyanions. ${ }^{51} \mathrm{~V}$ NMR studies, for example, are in progress (MIKKONEN and Kolehmainen 1994). As soon as better results are obtained in laboratory experiments, the behaviour of Mo, V, and $\mathrm{W}$ in soils could be more thoroughly discussed.

Table 3. Correlation between retained W (in $\mu \mathrm{g} / \mathrm{g}$ ) and desorbed $\mathrm{P}$ (in $\mu \mathrm{g} / \mathrm{g}$ ) at $\mathrm{pH} 3-6$.

\begin{tabular}{lccc}
\hline Soil & $\begin{array}{c}\text { Number of } \\
\text { samples }\end{array}$ & $\begin{array}{c}\text { Coefficient of } \\
\text { correlation }\end{array}$ & Slope \\
\hline soil 1 & 26 & 0.9629 & $0.097 \pm 0.005$ \\
soil 2 & 27 & 0.9702 & $0.079 \pm 0.004$ \\
soil 3 & 26 & 0.9588 & $0.065 \pm 0.004$ \\
\hline
\end{tabular}




\title{
References
}

BARber, S.A. 1984. Soil nutrient bioavailability. A mechanistic approach. John Wiley \& Sons, New York. 398 p.

BARROW, N.J. 1974. On the displacement of adsorbed anions from soil: 1. Displacement of molybdate by phosphate and by hydroxide. Soil Science 116: 423-431.

- 1989. Testing a mechanistic model. IX. Competition between anions for sorption by soil. Journal Soil Science 40: 415-425.

Cruywagen, J.J. \& Van Der Merwe, I.F.J. 1987. Tungsten(VI) equilibria: A potentiometric and calorimetric investigation. Journal of Chemical Society, Dalton Transactions: 1701-1705.

GoldberG, S. \& Traina, S.J. 1987. Chemical modeling of anion competition on oxides using the constant capacitance model-mixed-ligand approach. Soil Science Society of America Journal 51: 929-932.

Gorlach, E., Gorlach, K. \& Compata 1969. The effect of phosphates on the sorption and desorption of molybdates in the soil. Agrochimica 6: 506-512.

HarRison, A.T. \& HowarTh, O.W. 1985. Oxygen exchange and protonation of polyanions: a multinuclear magnetic resonance study of tetravanadophosphate(9-) and decavanadate(6-). Journal of Chemical Society, Dalton Transactions: 1953-1957.

LINDSAY, W.L. 1979. Chemical equilibria in soils. WileyInterscience, Brisbane. 449 p.

MAKSIMOVSKAYA, R.I. \& BURTSEVA, K.G. 1985. ${ }^{17} \mathrm{O}$ and ${ }^{183} \mathrm{~W}$ NMR studies of the paratungstate anions in aqueous solutions. Polyhedron 4: 1559-1562.

Mikkonen, A. \& Kolehmainen, E. 1994. ${ }^{51}$ V NMR studies on aqueous solutions of V(V) and V(IV). Department of Chemistry, University of Turku, Research Report No 1/1994, p. 77.

- \& TUMmavuORI, J. 1993a. Retention of vanadium(V), molybdenum(VI) and tungsten(VI) by kaolin. Acta Agriculturae Scandinavica, Section B. Soil and Plant Sci- ence 43: 11-15.

- \& Tummavuori, J. 1993b. Retention of molybdenum (VI) by three Finnish mineral soils. Acta Agriculturae Scandinavica, Section B, Soil and Plant Science 43: 206-212.

- \& Tummavuori, J. 1993c. Retention of tungsten(VI) by three Finnish mineral soils. Acta Agriculturae Scandinavica, Section B, Soil and Plant Science 43: 213217.

- \& Tummavuori, J. 1993d. Retention of vanadium(V) by three Finnish mineral soils. European Journal of Soil Science (In press)

Murali, V. \& Aylmore, L.A.G. 1983. Competitive adsorption during solute transport in soils; 3. A review of experimental evidence of competitive adsorption and an evaluation of simple competition models. Soil Science 136: 279-290.

Pettersson, L., Andersson, I. \& Öhman, L.-O. 1985. Multicomponent polyanions. 35. A ${ }^{31} \mathrm{P}$ NMR study of aqueous molybdophosphates. Acta Chemica Scandinavica A 39: 53-58.

POPE, M.T. 1983. Heteropoly and isopoly oxometalates. Springer-Verlag, Berlin. 175 p.

Roy, W.R., HASSETT, J.J. \& GRIFFIN, R.A. 1986a. Competitive interactions of phosphate and molybdate on arsenate adsorption. Soil Science 40: 203-210.

-, Hassett, J.J. \& Griffin, R.A. 1986b. Competitive coefficients for the adsorption of arsenate, molybdate, and phosphate mixtures by soils. Soil Science Society of America Journal 50: 1176-1182.

-, Hassett, J.J. \& GrifFin, R.A. 1989. Quasi-thermodynamic basis on competitive-adsorption coefficients for anionic mixtures in soils. Journal of Soil Science 40: 9-15.

Manuscript received March 1994

\section{SELOSTUS}

\section{Fosforin desorptio kolmesta suomalaisesta mineraalimaasta vanadaatin, molybdaatin ja volframaatin adsorption aikana}

\author{
AnNeli MikKonen ja Jouni Tummavuori
}

\author{
Jyväskylän yliopisto
}

Tutkittaessa molybdaatin, vanadaatin ja volframaatin adsorptiota kolmeen suomalaiseen mineraalimaanäytteeseen $10^{-4}$ tai $10^{-5} \mathrm{M}$ liuoksesta mitattiin myös adsorption aikana liuosfaasiin siirtyneen fosforin määriä. Adsorption etenemistä ja fosfaatin desorptiota seurattiin ajan funktiona kunkin maan luonnollisessa $\mathrm{pH}$ :ssa. Toisessa kokeessa mitattiin desorboitunut fosfori, kun tutkittiin vanadaatin, mo- lybdaatin ja volframaatin adsorptiota 72 tunnin aikana $\mathrm{pH}-$ alueella 2,3-7,5. Tulokset osoittivat, ettå molybdaatin, volframaatin ja vanadaatin läsnäolo pyrkii lisäämään liuosfaasissa olevan fosforin määrää.

Artikkelissa tarkastellaan lyhyesti myös molybdeenin, vanadiinin ja volframin ionimuotoja vesiliuoksissa. 